\title{
Strategi Pemerintah Kelurahan Dalam Pengembangan Sumberdaya Manusia Anak Putus Sekolah di Kampung Nelayan
}

\section{The Strategy of the Village Government in Developing Human Resources for School Dropouts in Fishermen's Villages}

\author{
Yorizal Tri Marzuki Gulo', Beby Masitho Batubara², Nina Angelia ${ }^{3}$ \\ Program Studi Adminitrasi Publik, Fakultas Ilmu Sosial dan Ilmu Poitik, \\ Universitas Medan Area, Indonesia
}

Disetujui: Oktober 2021; Direview: Oktober 2021;Diterima: Nopember 2021

\begin{abstract}
Abstrak
Penelitian ini dilakukan dengan tujuan untuk mengidentifikasi faktor penyebab anak putus sekolah dan strategi pemerintah kelurahan dalam mengembangkan SDM anak putus sekolah. Metode yang digunakan dalam penelitian ini adalah tipe penelitian deskriptif, yaitu penelitian yang bertujuan untuk menggambarkan dan mendeskripsikan objek dan fenomena yang diteliti. Penelitian ini menggunakan jenis penelitian deskriptif kualitatif dengan pendekatan studi lapangan. Data dikumpulkan melalui observasi, dokumentasi, dan wawancara terkait faktor penyebab dan strategi pemerintah kelurahan. Informan penelitian terdiri dari pemangku kepentingan terkait yaitu Lurah Kelurahan Belawan 1, Kepala Lingkungan XII Kampung Nalayan dan beberapa masyarakat yang bermukim di Kelurahan Belawan I Lingkungan XII Kampung Nelayan berjumlah 6 orang. Tehnik analisis data dengan menggunakan model analisis interaktif. Hasil dari penelitian ini menunjukkan bahwa faktor penyebab anak putus sekolah dikarenakan adanya faktor dari dalam diri anak dan juga dari luar diri. Sebagai langkah strategis yang diambil oleh pemerintah kelurahan untuk mengembangkan SDM anak putus sekolah tersebut yakni dengan menerapkan pendidikan kesetaraan, membuat dialog komunitas, mendirikan rumah zakat serta melaksanakan kegiatan keliling kampung. Dengan demikian, bahwa dapat ditarik kesimpulan permasalahan mengenai anak putus sekolah telah berhasil diminimalisir melalui strategi yang telah ditetapkan oleh pemerintah Kelurahan Belawan 1.
\end{abstract}

Kata Kunci: Anak Putus Sekolah, Pengembangan SDM, Strategi Pemerintah Kelurahan

\begin{abstract}
This research was conducted with the aim of identifying the factors that cause children to drop out of school and the strategy of the sub-district government in developing human resources for out of school children. The method used in this research is descriptive research type, namely research that aims to describe and describe the objects and phenomena studied. This research uses descriptive qualitative research with a field study approach. Data were collected through observation, documentation, and interviews related to the causal factors and strategies of the kelurahan government. Research informants consisted of relevant stakeholders, namely the Village Head of Belawan 1 Village, the Head of the XII Village of Nalayan Village and several people who live in the Belawan I Village of the XII Fisherman's Village, totaling 6 people. Data analysis techniques using interactive analysis models. The results of this study indicate that the factors that cause children to drop out of school are due to factors from within the child and also from outside. As a strategic step taken by the village government to develop human resources for these school dropouts, namely by implementing equality education, making community dialogues, establishing zakat houses and carrying out activities around the village. Thus, it can be concluded that the problem of school dropouts has been successfully minimized through the strategy set by the Belawan 1 Village government.
\end{abstract}

Keywords: School Dropout Children, Human Resource Development, Family Government Strategy.

How to Cite: Gulo, M.T.Y, Batubara, M.B., \& Angelia N. (2021). Strategi Pemerintah Kelurahan Dalam Pengembangan Sumberdaya Manusia Anak Putus Sekolah Di Kampung Nelayan. PUBLIKAUMA: Jurnal Ilmu Administrasi Publik UMA, Vol.9 (2): 1-8

*Corresponding author:

E-mail: yorizalmar03031998@gmail.com
ISSN 2549-1660 (Print)

ISSN 2580-2011 (Online) 


\section{PENDAHULUAN}

Berawal pada saat peneliti melakukan perjalanan di Kampung Nelayan Medan Belawan, terlihat banyak anak-anak bermain bersama teman-temannya di pantai. Selain itu, juga ada banyak anak-anak yang sudah berlayar bersama orang tuanya untuk menangkap ikan. Ada di antara mereka yang memancing, menyiapkan jala ikan dan membersihkan perahu. Padahal seusia mereka seharusnya berada di sekolah untuk belajar. Secara spontan, peneliti melakukan kegiatan wawancara kepada beberapa warga masyarakat sekitar. Mereka menyebutkan bahwa anak-anak tersebut sebagian besar banyak yang sudah putus sekolah dan bahkan tidak sekolah sama sekali (Syrawiyah, 2021). Keadaan ini sangat miris dimana anak-anak yang seusia mereka sedang menerima pelajaran di sekolah, akan tetapi mereka bekerja layaknya orang dewasa.

Pada tahun 2019, jumlah nelayan di Provinsi Sumatera Utara ada sebanyak 119.026 orang (Badan Pusat Statistik Provinsi Sumatera Utara, 2021). Menurut Satria dalam (Fefayosa, 2017) salah satu faktor yang menyebabkan sulitnya nelayan memperbaiki tingkat kesejahteraannya karena tidak memilki kapal dan alat tangkap yang memadai. Sementara yang kita ketahui bahwa alat-alat seperti kapal maupun alat tangkap ikan seperti jala adalah merupakan hal yang sangat penting tidak dapat lepas dari kehidupan dan kegiatan para nelayan.

Penduduk pesisir dikenal dengan masyarakat yang rentan dengan kemiskinan. Dalam kegiatannya memenuhi kebutuhan dasar seperti sandang, pangan dan papan sangat terbatas. Permasalahan di Kampung Nelayan, sebenarnya adalah masalah yang sudah terstruktural (sudah dari dulu), dan yang menjadi permasalahan pada saat ini adalah pada masyarakat itu sendiri. Kadang kala karena keadaan yang struktural menyebabkan keadaan yang turun-temurun (ayahnya berprofesi sebagai nelayan dan selanjutnya anaknya juga menuruskan profesi sebagai nelayan). Akibatnya, pekerjaan nelayan tetap diwariskan ke anak mereka. Dari keseharian mereka bekerja hanya mampu memenuhi kebutuhan hidup sehari-hari, sehingga anaknya tidak stagnan untuk memperoleh pendidikan, apalagi memperbaiki lingkungan sarana perumahan dan sebagainya.
Persoalan pendidikan ini tidak terlepas dari kemiskinan yang menjerat masyarakat pesisir (Fefayosa, 2017).

Berdasarkan data diketahui bahwa di Provinsi Sumatera Utara sendiri sejak tahun 2017 terdapat sebanyak 13.703 anak yang putus sekolah. Dimana pada tingkat SMA 3.501 siswa, untuk tingkat SMP sebanyak 5.003 siswa, sedangkan untuk tingkat SD 5.199 siswa (Yunita, 2018). Sementara diperkirakan 15.000 jiwa warga di Kecamatan Medan Belawan, Kota Medan tergolong miskin dan terdapat 1.800 anak putus sekolah setingkat SD SMP (Anwar, 2019). Di Kampung Nelayan sendiri ada sekitar 80\% anak putus sekolah. Sebagian besar penduduk Kampung Nelayan hanya tamatan SD. Selain itu, Wilayah Kampung Nelayan yang dipisahkan oleh laut dari daratan utama Kecamatan Medan Belawan membuat akses pendidikan di wilayah ini menjadi terhambat. Hal ini dibuktikan dengan fasilitas pendidikan yang minim berupa gedung sekolah yang ada di Kampung Nelayan. Hanya terdapat 1 gedung sekolah SD Negeri yang akan menampung ratusan anak usia sekolah yang ada di sana. Tentu dengan jumlah anak usia sekolah yang tidak sebanding dengan kelas yang ada membuat banyak anak yang tidak bisa bersekolah serta kualitas pendidikan pun akan menjadi terganggu.

Hal tersebut di atas menjadi faktor utama dibuatnya penelitian ini untuk mengetahui faktor penyebab anak putus sekolah di Kampung Nelayan dan strategi yang dibuat oleh pemerintah Kelurahan dalam menanani masalah tersebut. Putus sekolah adalah predikat yang diberikan kepada mantan peserta didik yang tidak mampu menyelesaikan suatu jenjang pendidikan, sehingga tidak dapat melanjutkan studinya ke jenjang pendidikan berikutnya (Gunawan, 2004).

Sementara (Dewi, 2014) menjelaskan bahwa putus sekolah adalah proses berhentinya siswa secara terpaksa dari suatu lembaga pendidikan tempat belajar. Anak putus sekolah yang dimaksud adalah terlantarnya anak dari sebuah lembaga pendidikan formal, yang disebabkan oleh berbagai faktor. Sedangkan Astari, I Gusti dan Made (2013) mengatakan putus sekolah adalah salah satu indikator yang berguna untuk megukur kemajuan sumber daya 
manusia pada bidang pendidikan pada tiap wilayah.

Lebih lanjut lagi (Dewi, 2014) mengungkapkan bahwa fenomena putus sekolah adalah suatu keadaan terhentinya aktivitas pendidikan pada anak-anak usia sekolah, baik itu pendidikan formal maupun pendidikan informal sebelum mendapatkan pengetahuan yang cukup untuk bertahan hidup dalam masyarakat.

(Purnama, 2014) menyebutkan bahwa salah satu penyebab anak putus sekolah adalah rasa minat yang rendah untuk bersekolah atau malas. Selain faktor yang berasal dari (faktor internal) anak didik sendiri, seperti faktor kemalasan dan ketidakmampuan diri. Ada juga karena faktor dari luar (faktor eksternal) anak didik, seperti ketiadaan biaya dan sarana pendidikan. Sebagaimana menurut Elike (Purwanti, 2016) faktor internal yang menyebabkan prestasi anak di sekolah tidak maksimal sehingga memicu terjadinya putus sekolah adalah intelegensi, motivasi, tingkat kesadaran serta tidak menyukai sekolah. Sedangkan untuk faktor eksternal yaitu ekonomi, sekolah serta sosial budaya masyarakat. Sementara menurut (Sugianto, 2017) secara garis besar ada 3 faktor utama yang menyebabkan anak untuk putus sekolah yang pertama keadaan anak itu sendiri yang memang senang bekerja dari pada belajar (Lim, 2008) menyarankan bahwa ada kebijakan sekolah yang membuat siswa putus sekolah tanpa disengaja. Sementara, (Reddy \& dan Sinha, 2010) menegaskan bahwa siswa didorong keluar dari sekolah karena kurangnya kapasitas di sekolah, seperti fasilitas, peraturan dan kualitas.

Oleh sebab itu, sangat diperlukan pengembangan SDM anak putus sekolah agar masa depan anak-anak tetap terpelihara. Apabila kita berbicara masalah pengembangan sumber daya manusia, maka dapat kita lihat dari dua aspek, yakni: dari segi kuantitas dan juga kualitas. Pengertian kuantitas menyangkut jumlah sumber daya manusia. Kuantitas sumber daya manusia ini tanpa disertai dengan kualitas sumber daya manusia maka pada dasarnya pendidik tidak akan baik peserta didik jika kualitas sumber daya pendidik tidak berjalan dengan baik maka akan jadi permasalahan dalam sumber daya pendidik, oleh sebab itu kualitas dan kuantitas dalam sumber daya manusia Pendidik itu penting didalam pendidikan (Sedarmayati, 2009).

Pada dasarnya tujuan utama pengembangan sumber daya manusia adalah meningkatkan produktifitas kerja seseorang dan mampu meningkatkan keterampilan dan motivasi. Dengan adanya pelatihan pengembangan SDM, maka telah dibuat beberapa tujuan dari pelatihan pengembangan sumber daya manusia tersebut dimana supaya manusia dapat memperoleh kemampuan untuk menjalankan tugas-tugas atau pekerjaanya, pengembangan sumber daya manusia sebagai upaya terencana yang dilakukan untuk meningkatkan kompetensi dalam pelatihan, pendidikan, dan pengembangan.

Seperti halnya dalam pengembangan sumber daya manusia anak-anak putuss sekolah, dalam melaksanakannya tentu dibutuhkan berbagai strategi untuk dapat terselenggara dengan baik. Selanjutnya, menurut Sofjan Assauri menyatakan bahwa dalam penyusunan strategi pada hakekatnya erat kaitannya dengan penetapan-penetapan keputusan yang harus diambil dan ditentukan dalam menghadapi para pesaing di dalam lingkungan kehidupan yang saling memiliki ketergantungan, sehingga perlu ada kegiatan yang diarahkan, terutama dalam mempkirakan perilaku satu dengan yang lainnya (Assauri, 2013).

\section{METODE PENELITIAN}

Penelitian ini tergolong tipe penelitian deskriptif, yaitu penelitian yang bertujuan untuk menggambarkan dan mendeskripsikan objek dan fenomena yang diteliti. Termasuk di dalamnya bagaimana unsur-unsur yang ada dalam variabel penelitian itu berinteraksi satu sama lain dan ada pula produk yang berlangsung (Siagian, 2011). Jenis penelitian ini adalah deskriptif kualitatif, melalui penelitian ini peneliti ingin mengetahui faktorfaktor yang menyebabkan anak putus sekolah dan strategi pemerintah kelurahan dalam meningkatkan SDM anak putus sekolah di Kelurahan Belawan I Lingkungan XII Kampung Nelayan.

Informan dalam penelitian memiliki peran yang sangat penting dalam pengambilan data dan informasi. Menurut (Afrizal, 2016) informan penelitian adalah orang yang memberikan informasi baik tentang dirinya 
ataupun orang lain atau suatu kejadian atau suatu hal kepada peneliti atau pewawancara mendalam. Informan tersebut terbagi 3 yakni informan kunci, informan utama dan informan tambahan. Yang menjadi informan kunci dalam penelitian ini adalah Lurah yaitu ibu Siti Maryam, S.Sos. Sementara itu, informan utama dalam penelitian ini adalah Kepala Lingkungan XII Kampung Nalayan yaitu ibu Sarawiyah. Adapun yang menjadi informan tambahan dalam penelitian ini adalah beberapa masyarakat yang bermukim di Kelurahan Belawan I Lingkungan XII Kampung Nelayan berjumlah 6 orang.

Selanjutnya Menurut (Sugiyono, 2015) teknik pengumpulan data merupakan langkah yang paling utama dalam penelitian, karena tujuan utama dari penelitian adalah mendapatkan data. Teknik pengumpulan data dapat dilakukan dengan observasi (pengamatan), interview (wawancara), dan dokumentasi. Kemudian metode analisis data, penelitian ini yakni pengumpulan data, reduksi data dan penyajian data (Huberman, 2012).

\section{HASIL DAN PEMBAHASAN}

Salah satu faktor putusnya sekolah anak di Kampung Nelayan disebabkan oleh kurangnya perhatian kepada anak dari orang tua. Orang tua memiliki sifat yang leluasa kepada anaknya untuk bertindak berdasarkan kemauannya sendiri. Hingga si anak lebih memilih bermain bersama dengan temantemannya. Selain itu, orang tua kurang memperhatikan anak-anaknya untuk belajar dan datang ke sekolah. Hingga pada akhirnya anak-anak di Kampung Nelayan tidak memiliki semangat belajar karena tidak ada pengawasan yang yang dilakukan secara berkala. Akibatnya banyak anak-anak di kampung tersebut hanya bisa menempuh pendidikan di tingkat sekolah dasar.

Terkait faktor penyebab anak putus sekolah di Kampung Nelayan, Kepala Lingkungan XII Kampung Nelayan menyatakan sebagai berikut.

"Di Kampung Nelayan ini ada begitu banyak anak putus sekolah dari berbagai tingkatan semua ada. Baik dari anakanak yang putus sekolah di tingkat SD, SMP maupun tingkat SMA. Ini dikarenakan masih minimnya perhatian terhadap si anak akan pentingnya pendidikan. Sebagian orang tua mengajari anaknya untuk bisa melaut dibandingkan pergi ke sekolah sehingga anak-anak mereka pun menjadi giat mencari uang dan mengesampingkan pendidikan. Selain itu, juga dikarenakan tingkat pendapatan masyarakat Kampung Nelayan ini juga masih rendah hanya bisa memnuhi kebutuhan seharihari sehingga terkendala orang tua untuk invesanaknya di dunia pendidikan" (Hasil Wawancara, 15 Januari 2021).

Perhatian orang tua sebenarnya memiliki peran penting dalam pembentukan setiap karakter anak untuk tetap termotivasi belajar dan mau menuntut ilmu. Perhatian orang tua tersebut bisa berupa pembimbingan dan pendampingan anaknya, menanyakan kedaan anaknya, mengajari cara belajar yang baik, membaca, bekerja dengan baik serta cara menghormati dan menghargai orang yang lebih desawa darinya. Sehingga perhatian orang tua sangat dituntut untuk terus dilakukan secara berkesinambungan agar tetap menjaga stabilitas karakter si anak yang dalam pertumbuhan dan perkembangan yang labil. Seperti kita ketahui bahwa anak-anak yang dalam tahap pertumbuhan dan perkembangan sangat membutuhkan lingkungan dan suasana yang mendukung karena akan berdampak pada cara kehidupannya di masa yang akan datang. Kehidupan yang baik yang diharapkan terbentuk dalam diri anak bisa berupa cara pergaulan yang baik, bekerja dengan cerdas, suka belajar hal-hal yang baru, rajin sekolah dan tidak berbuat onar di masyarakat.

Selanjutnya Orang tua di Kampung Nelayan lebih memilih dan mengajari anakanaknya untuk melaut. Mulai dari membersihkan sampan, membuat jaring, jemur ikan, dan menangkap ikan. Kegiatan ini mereka lakukan secara turun-temurun. Pengetahuan orang tua untuk mengajari anakanak mereka untuk bekerja lebih diutamakan dibandingkan menyekolahkannya. Sebagian orang tua menganggap bahwa pendidikan membutuhkan biaya yang besar dan hanya akan membuat pengeluaran semakin tinggi, tanpa memikirkan jauh ke depan untuk kebutuhan anaknya.

Hal ini juga disebabkan karena rendahnya pengetahuan orang tua yang hanya 
mengenyam pendidikan di Sekolah Dasar dan bahkan tidak sekolah sama sekali. Padahal peran orang tua akan kesadaran akan pentingnya pendidikan bagi kehidupan anakanaknya memiliki peran yang sangat penting dan tidak dapat terpisahkan dari kehidupan si anak. Bapak Supendi bekerja sebagai nelayan di Kampung Nelayan menyatakan sebagai berikut.

"Karena pendapatan bapak hanya berkisar satu juta perbulan sehingga kondisi ini membuat bapak kebingungan dalam memenuhi kebutuhan sehari-hari. Tanggungan bapak ada 4 orang anak dan juga istri. Sehingga bapak harus mengajak anak bapak yang pertama dan anak kedua untuk ikut melaut" (Hasil Wawancara, 18 Januari 2021).

Bapak Sumardi bekerja sebagai nelayan di Kampung Nelayan menyatakan sebagai berikut.

"Anak saya nomor 2 harus putus sekolah untuk saya ajak bersama melaut. Kami tidak memiliki sampan sendiri dan terpaksa kami harus menyewa dengan teman nelayan lainnya. Hal ini membuat kami sulit memuhi kebutuhan seharihari" (Hasil Wawancara, 19 Januari 2021).

Orang tua memiliki tugas dan tanggung jawab yang besar dalam menyekolahkan anaknya. Lantas bagaimana jika orang tua kurang pengetahuan dan kesadaran akan pentingnya pendidikan, hal tersebut akan berdampak negatif bagi si anak karena secara tidak langsung akan mempengaruhi cara dan pola pendampingan orang tua terhadap anaknya yang kurang memadai. Oleh karena pentingnya pengetahuan dan kesadaran orang tua akan pentinya pendidikan, maka sebaiknya orang tua terus dibekali sejak dini baik melalui sosialisasi atau pelatihan dan pembelajaran yang dilakukan secara formal maupun nonformal baik yang dilakukan oleh pemrintah setempat maupun organisasi atau komunitas tertentu.

Hingga saat ini di Kampung Nelayan masih hanya terdapat satu sekolah dasar negeri yang menampung banyak anak-anak di kampung tersebut. Untuk sekolah menegah pertama dan menengah atas masih belum tersedia. Dengan minimnya fasilitas pendidikan ini membuat anak-anak semakin susah mengakses dunia pendidikan. Selain itu, orang tua juga harus mengeluarkan biaya yang lebih besar untuk menyekolahkan anaknya jika harus melanjutkan pendidikannya, mulai dari biaya sekolah, uang transportasi (baik lewat laut/menyebrang maupun perjalanan daratan). Di Kampung Nelayan untuk setiap tarif penyeberangan $6.000-10.000$ ribu per orang (pulang-pergi).

Ibu Adinda sebagai ibu rumah tangga di Kampung Nelayan menyatakan sebagai berikut.

"Anak saya hanya tamatan SD dan tidak melanjutkan ke tingkat SMP dikarenakan lokasinya yang jauh dari kampung kami. Harus menaiki sampan untuk bisa menyebrang dan juga biaya transportasi darat yang dikeluarkan setiap hari membuat kami berpikir untuk menunda anak kami melanjutkan studinya" (Hasil Wawancara, 16 Januari 2021).

Kesediaan sarana dan prasaran yang memadai akan lebih mudah anak-anak untuk menjangkaunya serta para orang tua juga dipermudah dalam penghematan biaya. Jarak yang dekat dengan sekolah dan tidak banyak mengeluarkan biaya yang besar akan lebih dipilih karena akan lebih mengurangi pengeluaran yang sangat besar. Namun lain halnya yang terjadi di Kampung Nelayan dimana hingga saat ini sekolah yang tersedia hanya untuk Sekolah Dasar. Bagi anak-anak yang telah tamat SD dan ingin melanjutkan sekolahnya di tingkat SMP dan SMA terpaksa harus keluar dan harus menyeberang untuk bisa sampai ke daratan. Mereka harus mengeluarkan biaya setiap hari untuk keperluan transportasi mereka. Hal ini akan membuat para orang tua di Kampung Nelayan semakin terpuruk dan membuat mereka kesulitan dalam menyekolahkan anaknya. Kebutuhan dasar yang susah dipenuhi apalagi memberikan kesempatan kepeda anaknya untuk mengenyam pendidikan serta membangun perumahan dan sebagainya.

Selanjutnya jumlah tanggungan di Kampung Nelayan juga menjadi salah satu faktor putusnya anak putus sekolah. Tak jarang ditemui setiap rumah tangga ada yang memiliki anak 5-8 orang. Ini membuat orang tua sulit untuk memenuhi kebutuhan dasar karena jumlah tanggungan yang banyak hingga anak menjadi korban putus sekolah. Jika 
kebutuhan sehari-hari saja tidak cukup bagaiman bisa anak-anak mereka diberikan kesempatan memperoleh pendidikan.

Miyah yang bekerja sebagai ibu rumah tangga sekaligus orang tua dari anak putus sekolah menyatakan sebagai berikut.

"Suami ibu hanya seorang buruh, dia biasanya berangkat kerja dari jam 07:00 WIB pagi dan pulang sore hari sekitar pukul 17:00. Gaji bapak perhari tidak tetap kadang ada seratus ribu dan juga delapan puluh ribu. Kadang setelah pulang ke rumah hanya membawa uang tiga puluh ribu sampai empat puluh ribu. Karena saat kerja bapak juga beli makan dan minum sehingga sisa gajinya tinggal sikit. Keadaan orang ibu di sini memang susah nak, kebutuhan sehari-hari saja sangat terbatas" (Hasil Wawancara, 21 Januari 2021).

Bapak Saiful Bahri yang bekerja sebagai nelayan menyatakan sebagai berikut.

"Jumlah tanggungan bapak banyak sehingga bapak kesulitan memenuhi kebutuhan kami sehari-hari. Istri bapak hanya sebagai ibu rumah tangga belum ada pekerjaan tetap. Anak bapak juga terpaksa harus putus sekolah biaya yang dibutuhkan tidak ada. Bapak hanya bisa sekolahkan di tingkat SD saja" " (Hasil Wawancara, 16 Januari 2021).

Setiap anggota keluarga yang ada di dalam setiap rumah tangga adalah suatu beban ekonomi yang melahirkan suatu beban sosial yang harus dipenuhi dan dipukul dipundaknya oleh seorang kepala rumah tangga yang merupakan tulang punggung dalam memenuhi dan menafkahi keluarganya. Di Kampung Nelayan, jumlah tanggungan yang ditanggung keluarga miskin akan berpengaruh pada taraf atau tingkat kehidupannya dimana perekonomiannya yang sangat memprihatinkan. Banyak jumlah tanggungan dalam rumah tangga akan mempengaruhi tingkat pengeluaran konsumsi yang secara langsung serta kebutuhan lainnya yang tidak seara langsung bagi keluarga yang bersangkutan.

Selanjutnya kurangnya pengawasan dari orang tua membuat si anak untuk terus berkelakuan sesuka hati. Anak-anak lebih suka bermain dengan teman-temannya dibanding datang ke sekolah. Tak jarang ditemukan anakanak tersebut mulai masuk dalam pergaulan yang buruk seperti merokok. Hal ini membuat mereka malas dan mengesampingkan pendidikan.

Sifat malas yang ada dalam diri anakanak Kampung Nelayan ini disebabkan karena kurangnya semangat dan motivasi dalam setiap menjalankan kehidupannya. Tak jarang di antara mereka yang selalu tidak mengindahkan perkataan orang tua mereka seperti tidak mau membantu menyelesaikan pekerjaan rumah dan lebih memilih bermain bersama teman-teman mereka. Akibatnya banyak di antara mereka juga menjadi malas untuk belajar hingga pada akhirnya memilih untuk berhenti sekolah. Oleh sebab itu, seharusnya peranan orang tua perlu ditingkatkan dalam memberikan pendampingan sepenuhnya terhadap anakanak di Kampung Nelayan agar tetap hidup dalam koridor yang positif dan menjauhkan diri dari sifat malas.

Bapak Hermasyah yang merupakan tokoh pemuda di Kampung Nelayan menyatakan sebagai berikut.

"Rata-rata anak-anak di sini memiliki rasa malas untuk sekolah atau belajar. Banyak anak-anak yang lebih memilih untuk ikut orang tua melaut karena nanti akan langsung dapat uang setelah dapat hasil tangkapan. Selain itu, pergaulan mereka juga kurang baik dimana anak-anak di sini lebih memilih untuk jalan-jalan kesana ke mari dari pada sekolah" (Hasil Wawancara, 19 Januari 2021).

Selanjutnya, pergaulan anak-anak putus sekolah di Kampung Nelayan sudah mulai memburuk dimana lemahnya moral mereka dikarenakan kurang perhatian yang penuh dari para orang tua dan membebaskan anaknya untuk bergaul dengan siapa saja. Lingkungan yang merupakan tempat tumbuh dan berkembangnya si anak akan membawa pengaruh yang besar terhadap cara dan pola perilakunya. Jika lingkungannya memberikan sumbangan yang positif, maka secara otomatis akan berdampak pada perilaku yang baik dan terpuji. Sebaliknya, jika lingkungannya hanya mampu memberikan sumbangan yang negative, maka tidak heran si anak akan 
membawa pergaulan yang kurang baik tersebut dimana ia berada.

Untuk mengurangi jumlah anak putus sekolah di Lingkungan XII Kampung Nelayan, pemerintah Kelurahan Belwan 1 telah menyusun strategi yakni dengan pelaksanaan program pendidikan kesetaraan paket $A, B$ dan C. Adapun perencanaan pemerintah Kelurahan Belawan 1 dalam program kesetaraan paket $\mathrm{A}$, $B$ dan $C$ yakni sebelum melakukan proses pembelajaran kepada peserta didik setiap tutor harus membuat perangkat pembelajaran atau modul pembelajaran yang akan diajarkan. Sehingga hal ini nantinya akan mendukung proses pembelajaran dengan baik. Selain itu, juga telah ditetapkannya target dari kegiatan program pendidikan kesetaraan paket A, B dan $C$ yakni agar dapat meluluskan peserta didik setiap tahunnya, memberikan kesempatan untuk melanjutkan pendidikan dan memberikan wawasan berupa keterampilan hidup yang akan membantu mereka dalam beradaptasi dan mampu menunjukkan sikap perilaku yang positif yang pada akhirnya mereka mampu menghadapi setiap tuntutan dan tantangan kehidupan sehari-hari secara efektif dan produktif.

Lurah Kelurahan Belawan, menyatakan sebagai berikut.

"Seperti kita ketahui bahwa di Lingkungan XII Kampung Nelayan memang ada begitu banyak ana-anak putus sekolah. Tentunya hal itu tidak kita biarkan begitu saja, akan tetapi kita akan adakkan atau berikan beberapa langkah strategi sebagai upaya penangan dalam mengurangi jumlah anak putus sekolah. Kebijakan yang kita ambil di antaranya pelaksanaan progam paket $\mathrm{A}$, $B$ dan paket $C$ untuk kemudian menjadi alternative bagi anak-anak putus sekolag di Kampung Nelayan ini bisa mengenyam pendidikan layaknya pendidikan pada umumnya. Selain itu, kita juga bentuk sebuah dialog komunitas untuk mejadi media bagi Kampung Nelayan memberikan aspirasinya dan mengembangkan keterampilan mereka" (Hasil Wawancara, 25 Januari 2021).

Di sisi lain, ditemukan bahwa dalam pelaksanaan paket $\mathrm{A}, \mathrm{B}$ dan $\mathrm{C}$ sebagai program pendidikan kesetaraan di Kampung Nelayan juga tidak terlepas dari beberapa kendala di antaranya kurang rasa kesadaran dari peserta didiknya, karena dilihat masih banyak perserta didik yang tidak hadir dalam proses pembelajaran, bahkan saat ujian pun tidak hadir. Namun, demikian masyarakat Kampung Nelayan menyambut dengan baik dari program pendidikan kesetaraan ini karena melalui program tersebut akan mempermudah mereka terutama para orang tua untuk menyekolahkan anaknya.

Selanjutnya pelaksanaan dialog komunitas. Pelaksanaan dialog komunitas ini dibuat untuk mempermudah dalam mengamati dan menganalisis setiap permasalahan yang ada di Kampung Nelayan. Salah satu fokusnya adalah untuk melihat jumlah anak-anak putus sekolah serta penyebabnya, masalah narokoba dan kenakalan remaja. Dengan adanya program ini akan menjadi media untuk pemerintah Kelurahan Belawan 1 untuk memantau dan mengawasi setiap permasalahan yang ada di Kampung Nelayan salah satunya mengenai anak putus sekolah. Melalui program ini mempermudah untuk membuat suatu kebijakan baru terhadap masalah yang ada.

Kepala Lingkungan XII Kampung Nelayan menyatakan sebagai berikut.

"Di sini khususnya di Lingkungan XII Kampung Nelayan pemerintah Kelurahan Belawan 1 telah menyiapkan beberapa alternatif untuk mengembangkan SDM anak-anak putus sekolah. Di antaranya dengan mendirikan rumah zakat yang bertujuan untuk sosialisasi pendidikan, selan itu, pihak pemerintah kelurahan melaksanakan kegiatan keliling kampung bersama dengan pemuda masjid untuk memberikan berbagai pengetahuan yang baru salah satunya bidang pendidikan dan kesehatan" (Hasil Wawancara, 25 Januari 2021).

Dialog komunitas yang dilakukan di Kampung Nelayan sendiri melibatkan tokoh pemuda, tokoh masyarakat, Kepala Lingkungan, tokoh agama dan juga masyarakat sekitar untuk ikut berdiskusi terkait masalah yang sedang atau sudah terjadi di kampung tersebut. Topik mengenai masalah anak putus 
sekolah menjadi sesuatu yang tidak dapat dipisahkan dari kampung tersebut.

\section{SIMPULAN}

Berdasarkan pembahasan sebelumnya, maka dapat diambil sebuah simpulan bahwa faktor penyebab anak putus sekolah di Kampung Nelayan disebabkan karena adanya faktor internal yang berasal dari dalam diri anak putus sekolah itu sendiri seperti rasa malas dan tidak ada semangat untuk sekolah. Selanjutnya faktor eksternal yang membuat anak putus sekolah di Kampung Nelayan yaitu karena keadaan ekonomi atau penghasilan orang tua yang tidak memadai, fasilitas sekolah yang masih kurang lengkap serta pergaulan dan pengaruh lingkungan yang tidak terkendali.

Untuk mengembangkan sumber daya manusia khususnya anak-anak putus sekolah di Kampung Nelayan tersebut pemerintah kelurahan telah membuat berbagai strategi yakni dengan menerapkan program kesetaraan (program paket A, B dan C) serta melaksanakan dialog komunitas. Melalui kegiatan tersebut diharapkan SDM anak-anak putus sekolah dapat berkembang dan tetap terpelihara agar mampu menjadi pribadi yang memiliki integritas dalam memformulasikan setiap langkah kehidupannya.

\section{DAFTAR PUSTAKA}

Afrizal. (2016). Metode Penelitian Kualitatif. PT Raja Grafindo Persada.

Anwar, C. (2019). 15.000 Warga Medan Belawan Miskin, 1.800 Anak Putus Sekolah. https://medanbisnisdaily.com/news/online /read/2019/12/29/96851/15_000_warga_ medan_belawan_miskin_1_800_anak_putus_s ekolah/

Assauri, S. (2013). Strategic Marketing: Sustaining Lifetime Customer Value. Rajawali Pers.

Badan Pusat Statistik Provinsi Sumatera Utara. (2021). Jumlah Nelayan menurut Kategori (orang), $2008 \quad$ - 2019. https://sumut.bps.go.id/statictable/2021/0 4/21/2388/jumlah-nelayan-menurutkategori-orang-2008---2019.html

Dewi, N. A. K. A. Z. dan I. K. D. (2014). Analisis Faktor-Faktor Penyebab Anak Putus Sekolah Usia Pendidikan Dasar Di Kecamatan Gerokgak Tahun 2012/2013. Pendidikan Ekonomi, 1. https://ejournal.undiksha.ac.id/index.php/JJ PE/article/view/1898/1650
Fefayosa, S. (2017). Faktor-faktor penyebab anak putus sekolah di daerah pesisir lorong melati kelurahan belawan 1 kecamatan medan belawan kota medan.

Gunawan. (20004). Sosiologi Pendidikan: Suatu Analisis Sosiologi Tentang Berbagaiproblem Pendidikan. Rinekacipta.

Huberman, M. B. (2012). Analisis Data Kualitatif. UI Press.

Lim, R. W. R. and S. A. (2008). Why Students Drop Out of School: A Review of 25 Years of Research. University of California. https://www.issuelab.org/resources/11658 /11658.pdf

Purnama, D. T. (2014). Fenomena Anak Putus Sekolah Dan Faktor penyebabnya di Kota Pontianak. Sosiologi, 1. https://adoc.pub/fenomena-anak-putussekolah-dan-faktor-penyebabnya-di-kotap.html

Purwanti, L. (2016). Penyebab Putus Sekolah Pada Siswa Sekolah Dasar Di Kecamatan Tapen Kabupaten Bondowoso Pada Kurun Waktu 2010-2015. Universitas Jember.

Reddy, A. N., \& dan Sinha, S. (2010). School Dropouts or Pushouts? Overcoming Barriers for the Right to Education. Centre for International Education, Department of Education, School of Education \& Social Work, Essex House, University of Sussex. https://assets.publishing.service.gov.uk/me dia/57a08b0e40f0b64974000938/PTA40.p df

Sedarmayati. (2009). Manajemen Sumber Daya Manusia. PT Refika Aditama.

Siagian, S. P. (2011). Manajemen Sumber Daya Manusia. Bumi Aksara.

Sugianto, E. (2017). Faktor Penyebab Anak Putus Sekolah Tingkat SMA di Bukit Lipai Kecamatan Batang Cenaku Kabupaten Inderagiri Hulu. Jom Fisip, 4.

Sugiyono. (2015). Metode Penelitian Kualitatif. Alfabeta.

Yunita, N. W. (2018). Baca artikel detiknews, "Cagub Edy: Ironis, Banyak Anak Sumut Putus Sekolah" selengkapnya https://news.detik.com/berita/d4003112/cagub-edy-ironis-banyak-anaksumut-putus-sekolah. Download Apps Detikcom Sekarang https://apps.detik.com/detik/. https://news.detik.com/berita/d4003112/cagub-edy-ironis-banyak-anaksumut-putus-sekolah 